\title{
Beleza e Ciência
}

\author{
J. M. B. Lopes dos Santos \\ CFUP/ Universidade do Porto \\ jlsantos@fc.up.pt
}

\section{CITAÇÃO}

Lopes dos Santos, J.M.B. (2018)

Beleza e Ciência,

Rev. Ciência Elem., V6(03):063.

doi.org/10.24927/rce2018.063

\section{EDITOR}

José Ferreira Gomes,

Universidade do Porto

\section{EDITOR CONVIDADO}

João Lopes dos Santos,

Universidade do Porto

\section{RECEBIDO EM}

20 de setembro de 2018

\section{ACEITE EM}

23 de setembro de 2018

\section{PUBLICADO EM}

04 de outubro de 2018

\section{COPYRIGHT}

(C) Casa das Ciências 2018.

Este artigo é de acesso livre, distribuído sob licença Creative Commons com a designação CC-BY-NC-SA 4.0, que permite a utilização e a partilha para fins não comerciais, desde que citado o autor e a fonte original do artigo.

rce.casadasciencias.org

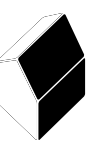

Os físicos e matemáticos usam frequentemente conceitos estéticos para se referir às suas descobertas. Dirac, em particular, valorizava a beleza como critério de verdade:

"It seems that if one is working from the point of view of getting beauty in one's equations, and if one has really a sound insight, one is on a sure line of progress. If there is not complete agreement between the results of one's work and experiment, one should not allow oneself to be too discouraged, because the discrepancy may well be due to minor features that are not properly taken into account and that will get cleared up with further development of the theory."

Eis a famosa equação de Dirac:

$$
(i \not b-m) \psi=0
$$

Podemos admirar a economia de símbolos, ou a beleza dos tipos usados, mas em que medida é bela esta equação? Como compará-la com o Bal du Moulin de la Gallete de Renoir, ou com o teto da Capela Sistina de Michelangelo?

Temos que reconhecer que a beleza a que se refere Dirac e tantos físicos e matemáticos é iniciática, reservada a bons conhecedores do significado e alcance das equações e teorias, e do contexto em que se inserem. Esta equação, para o seu descobridor, era o pináculo de uma imponente estrutura, que caracterizou de modo algo grandiloquente:

"The underlying physical laws necessary for the mathematical theory of a large part of physics and the whole of chemistry are thus completely known."

Concorde-se ou não com esta caracterização, o certo é que quem explora a equação de Dirac não pode deixar de ficar impressionado com o poder da síntese que realiza entre a Relatividade e a Mecânica Quântica, que the assegura, realmente, um papel fulcral em quase toda a Física e toda a Química. Unificar uma gama tão vasta de fenómenos com uma ideia que se expressa com tanta economia e simplicidade é o que os Físicos tomam como "belo". Mas é precisamente por causa da especificidade deste conceito de "belo" que não esperamos ver filas de turistas horas à espera para contemplar a equação de Dirac, como fazem no museu do Vaticano ou na Galeria degli Uffizi em Florença.

Os valores estéticos, contudo, são património comum da humanidade e os cientistas deles partilham, embora a sua sensibilidade possa ser "colorida" pela sua vivência da ciência. 
Uma das áreas mais ricas em imagens de apelo universal é a de mecânica de fluidos. A razão talvez tenha a ver com a inexistência de escalas intrínsecas de tempo e comprimento. É precisamente por essa razão que os fractais têm um apelo tão forte ao nosso sentido estético, ao permitirem estruturas delicadas, auto-semelhantes, geradora de surpresas inesgotáveis, à medida que a nossa atenção se prende em detalhes cada vez mais finos. No caso de fluidos, meios contínuos, as equações que descrevem o seu movimento não contêm parâmetros de comprimento intrínsecos, e são as dimensões dos obstáculos ou fronteiras sólidas que acabem por definir a escala das estruturas dos escoamentos.

Seja como for, a descoberta que a esteira do escoamento do ar à volta de uma bola de ténis, ou de uma asa de avião, apresenta semelhanças com a que ocorre num arquipélago como o das Canárias, numa escala de centenas de quilómetros, não pode deixar de nos surpreender e maravilhar.

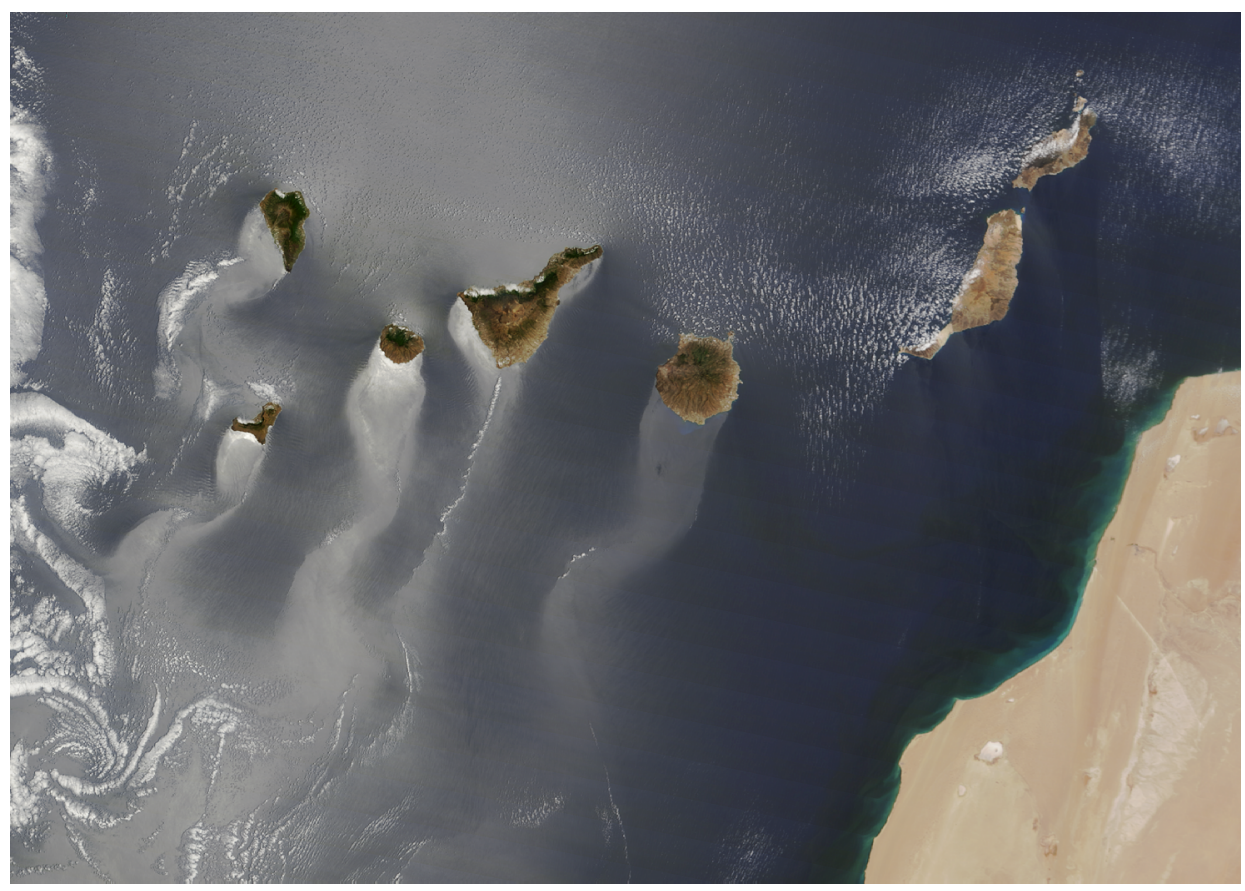

FIGURA 1. Os ventos dominantes nas Canárias sopram de Nordeste e a presença das ilhas cria uma esteira na atmosfera, que fica visível porque afeta a reflexão da luz no mar. (fonte: NASA)

A imagem da capa foi obtida pelo MODIS (Moderate Resolution Imaging Spectroradiometer) da NASA, um satélite que cobre toda a superfície da Terra em 1 a 2 dias em 36 bandas espectrais. Os ventos afetam as características da superfície do oceano, agitando ondas picadas em certos locais e alisando-a noutros. Isso origina diferenças no modo como a luz é refletida no oceano e torna visível a esteira do escoamento da atmosfera à voltas das Ilhas Canárias. De acordo com a experiência dos mareantes, no sotavento cruzam-se frequentemente ventos com direção oposta aos ventos dominantes do barlavento (que sopram de nordeste) e a turbulência resultante é visível numa longa linha ondulada de nuvens, que se estende centenas de quilómetros a sul de Tenerife, a segunda ilha a contar da direita. 